\title{
G

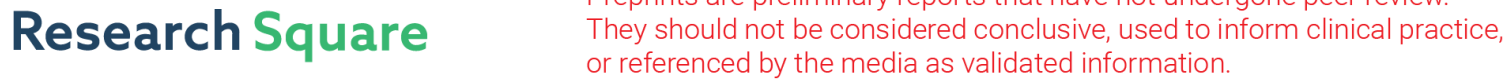 \\ Exploring the temporal dynamics of the fungal microbiome in rootstocks, the lesser-known half of the grapevine crop
}

\section{David Gramaje ( $\nabla$ david.gramaje@csic.es )}

Consejo Superior de Investigaciones Cientificas https://orcid.org/0000-0003-1755-3413

\section{Ales Eichmeier}

Mendel University in Brno

\section{Milan Spetik}

Mendel University in brno

\section{María Julia Carbone}

Universidad de la República Uruguay: Universidad de la Republica Uruguay

\section{Rebeca Bujanda}

Consejo Superior de Investigaciones Cientificas

\section{Jessica Vallance}

INRAE: Institut National de Recherche pour l'Agriculture I'Alimentation et l'Environnement

\section{Patrice Rey}

INRAE: Institut National de Recherche pour l'Agriculture I'Alimentation et l'Environnement

\section{Research article}

Keywords: Cadophora luteo-olivacea, Culture-independent analysis, Fungal microbiome, Grapevine nursery, Grapevine trunk diseases, High-throughput amplicon sequencing, Vitis vinifera

Posted Date: November 8th, 2021

DOI: https://doi.org/10.21203/rs.3.rs-1044951/v1

License: (c) (i) This work is licensed under a Creative Commons Attribution 4.0 International License. Read Full License

Version of Record: A version of this preprint was published at Journal of Fungi on April 20th, 2022. See the published version at https://doi.org/10.3390/jof8050421. 


\section{Abstract \\ Background}

Rootstocks are the link between soil and scion in grapevine, and they can either provide tolerance to abiotic and biotic stresses, and regulate yield and grape quality. The vascular system of grapevine rootstocks is still an underexplored niche despite its potential for hosting beneficial and pathogenic microorganisms. The purpose of this study was to investigate the changes in the composition of fungal communities in 110 Richter and 41 Berlandieri rootstocks at different stages of the grapevine propagation process and to measure the absolute abundance and dynamic changes of Cadophora luteoolivacea, a common pathogen associated with Petri disease of grapevine.

\section{Results}

Taxonomic analysis revealed that the fungal community predominantly consisted of phyla Ascomycota in all steps of the propagation process. The alpha-diversity of fungal communities differed among sampling moments for both rootstocks, with richness and fungal diversity in the vascular system decreasing throughout the propagation process. The core microbiome was composed by the genera Cadophora, Cladosporium, Penicillium and Alternaria in both rootstocks, while the pathogenic genus Neofusicoccum was identified as a persistent taxon throughout the propagation process. Fungal functionality analysis showed that the relative abundance of plant pathogens associated with trunk diseases increased towards the last stage in nurseries. Regarding $C$. luteo-olivacea, significant correlations between sequencing reads and droplet digital PCR (ddPCR) was observed.

\section{Conclusions}

Fungal communities in the vascular system of grapevine rootstocks differed among the different stages of the propagation process in nurseries. Numerous genera associated with potential biocontrol activity and grapevine trunk diseases have been identified. Understanding the large diversity of fungi in the rootstock vascular tissue and the interactions between fungal microbiota and grapevine will help developing sustainable strategies for grapevine protection.

\section{Introduction}

The concept of commercial grapevine nursery, where grafted plants are propagated to be sold to growers, is something that has been developed largely since the late 19th century in Europe with the introduction of the North American aphid Phylloxera [1]. During the 1980s, grapevine propagation methods of grafted plants were modernized by the use of rapid machine-grafting procedure, in particular the omega bench grafting [2]. Grapevine is relatively an easy plant to propagate, but the process involves numerous steps with high organization and skill requirements to produce millions of vines of high quality [3]. A precise 
description of the stages and practices for the production of grafted plants was reviewed by Gramaje and Armengol [4]. Dormant cuttings are taken from rootstock and scion mother vines for bench grafting, rooting, or field budding. Basically, nursery practices include cold storage, disbudding and hydration of rootstock/scion cuttings, grafting, and callusing and rooting of grafted plants [4].

Grapevine is considered a plant model system for research on fungal and bacterial microbiota. The novel high-throughput sequencing (HTS) approaches have been recently used to outline the microbiome on grapevine organs such as root, berry and leaf in mature vines due of its importance with grape production, fruit and foliar diseases management, and the biological implication of endemic microorganisms with the local characteristic of a wine [5-7]. Culture-dependent microbial approaches have been used to reveal the microbiota present in the grapevine endosphere [8-11]. Nonetheless, cultureindependent high-throughput amplicon sequencing (HTAS) techniques have recently been deployed to increase the microbiome portrait of grapevine woody organs such as trunk and cane [12-18].

While most of the abovementioned research has focused on scions, little is known about rootstocks, the lesser-known half of the grapevine crop. Rootstocks are the link between soil and scion in grafted woody crops, and they play a fundamental role in viticulture since the introduction of the aphid Phylloxera. Numerous studies have demonstrated the significant effect that grapevine rootstocks have on the scion performance. They can provide tolerance to different abiotic and biotic stresses, and they are also a major determinant of grapevine vigor, and consequently, of yield and grape quality [2]. The vascular system of grapevine rootstocks is still an unexplored niche despite its potential for hosting pathogenic and beneficial microorganisms. For instance, the presence of endogenous pathogens in grapevine rootstock planting material in newly established vineyards has been pointed out as a cause of yield losses, poor vine vigor, and long-term economic losses to industry [19]. Some of the most common pathogens that are able to infect rootstock planting material in grapevine nurseries include fungi associated with black-foot and Petri diseases [4]. Up to 28 Cylindocarpon-like asexual morphs have been reported to cause black-foot disease $[20,21]$. Vines affected by black-foot show necrotic lesions on roots and black discoloration at the base of the rootstock [20]. Petri disease is caused by several ascomycetous fungi, including the cosmopolitan species Cadophora luteo-olivacea. This vascular pathogen has been widely isolated from diseased vines worldwide [22-25], as well as from remote habitats such as decaying wood in the Antarctica [26] and deep-sea sediments in the Irish Atlantic Ocean [27]. Cross-sections of Petri disease affected wood reveal black spots in the xylem vessels and black to brown vascular streaking. Potential inoculum sources of these fungi in grapevine nurseries include mother blocks, hydration tanks, grafting machines, callusing rooms, and nursery fields [4].

Plant-associated microbiome is diverse and complex. There is still a limited understanding of the mechanisms and factors that establish and maintain specific plant-associated microbial communities, and what stimulate the appropriate balance of different microbes. A better understanding of the microbiota-plant interaction during the early stages of the grapevine propagation process would help enhance applications that promote protection against pathogens and grapevine growth. The dynamics of a single fungal community over time can reveal in more detail about community member interactions 
than collecting samples at one-time snapshot from different communities in similar niches. These temporal dynamics of the fungal microbiome occurring in propagating material has not been studied so far by HTAS, and data available is only referred in the context of culture dependent approaches in specific stages of the production of vines $[11,23,28]$.

We tested the following hypotheses: (1) the composition and diversity of fungal microbiome that inhabit the vascular system of grapevine rootstocks changes according to the practice in the propagation process; (2) fungal pathogens abundances are enhanced after specific procedures in the propagation process; (3) nursery practices affect the metabolic function of the fungal communities and (4) some GTD pathogens are primary settlers of the grapevine rootstock vascular systems and can interact each other during the propagation process. The objective was therefore to investigate the changes in the composition of fungal communities at different stages of the grapevine propagation process by HTAS. In addition, we use droplet digital PCR (ddPCR) approach to measure the absolute abundance and dynamic changes of $C$. luteo-olivacea, a common pathogen associated with Petri disease of grapevine that affects planting material and young vines worldwide.

\section{Materials And Methods 2.1. Planting material}

Dormant grapevine cuttings of rootstocks 110 Richter (110 R) and 41 Berlandieri (41 B) were obtained from commercial nursery mother fields in Logroño (northern Spain). Two stocks of 15 cuttings per rootstock were used. Each stock was collected in different mother fields separated by $800 \mathrm{~m}$. Rootstock mother vines were 12-year-old and were cultivated along the ground from a self-supporting crown approximately $40 \mathrm{~cm}$ above the soil surface. Within each mother field, the 15 cuttings were randomly collected from five plants near the crown of the mother vine. All rootstocks' cuttings were $40-\mathrm{cm}$ long and $1.5-\mathrm{cm}$ wide. Data from each rootstock were analyzed independently due to the previously reported grapevine rootstock genetic control of the microbiome [29], and the variable degree of susceptibility of each grapevine rootstock to fungal trunk pathogen infections [30, 31].

\subsection{Wood sample collection}

Planting material followed the fundamentals of the standard grapevine propagation process described by Gramaje and Armengol [4]. Cuttings were collected from rootstock mother plants in December 2017 and brought immediately to the laboratory for sampling (sampling moment 1 ). A non-destructive method based in a $0.5 \mathrm{~mm}$ micro drill MICROMOT 50/EF (Proxxon micromot, Madrid, Spain) was used to collect grapevine wood from the xylem vessels of $110 \mathrm{R}$ and $41 \mathrm{~B}$ rootstocks [32]. Woody tissues were collected from the base ( $1 \mathrm{~cm}$ above the basal part of the cutting), medium and apical ( $1 \mathrm{~cm}$ below the top of the cutting) part of each rootstock cutting. In each plant part, bark was first disinfected with $70 \%$ ethanol, partially opened in a $1 \mathrm{~cm}^{2}$ flap with a sterile scalpel, and $50 \mathrm{mg}$ of woody tissue was collected in sterile Eppendorf tubes. Woody tissue from the three plant parts was mixed for DNA extraction. Micro holes were covered with Parafilm after drilling [32]. 
Cuttings were then held in cold storage at $2{ }^{\circ} \mathrm{C}$ with $90 \%$ humidity until March 2018 . Following cold storage, rootstock cuttings were soaked in water for $24 \mathrm{~h}$. After hydration, woody tissues were collected from the same plant parts and following the same procedure as described before (sampling moment 2). Rootstock cuttings were then bench-grafted onto Tempranillo scion cuttings of the clone 1033 using an omega-grafting machine. Scion cuttings were randomly collected from a single mother field near the rootstock mother blocks. Following grafting, the graft unions were dipped in a melted wax formulation to encouraged graft union callus development. Grafted plants were packed in boxes with sterile water and placed in a callusing room at $26^{\circ} \mathrm{C}$ and $80 \%$ humidity for 20 days, until callus formed at the basal part of the plant and around the graft union. Following successful callusing, grafts were removed from the callusing boxes and woody tissues were collected again following the same procedure as described before. The apical part consisted in rootstock wood collected $1 \mathrm{~cm}$ below the graft union (sampling moment 3). Grafted vines were then transported and planted in an open-root field nursery in May 2018 with an in-plant spacing of $10 \mathrm{~cm}$. Vines followed a regular program of drip irrigation and weed control. Dormant field finished plants were lifted in December 2018 by hand. Woody tissues were collected from the same rootstock parts following the same procedure as described before (sampling moment 4). No biocontrol agents or chemicals were applied during the different stages of the propagation process.

\subsection{DNA extraction, sequencing and data analysis of the high-throughput amplification assay}

DNA was extracted from the xylem tissue collected in each sampling moment using the i-genomic Plant DNA Extraction Mini Kit (Intron Biotechnology, South Korea). Quantification of DNA yields from each sample was performed by the Invitrogen Qubit 4 Fluorometer with Qubit dsDNA HS Assay (Thermo Fisher Scientific, Waltham, USA), and the extracts were adjusted to $10 \mathrm{ng} / \mu \mathrm{l}$. Samples of each plant stock (15 cuttings/grafted plants) were then pooled in groups of three, resulting in a total of five replicates for every batch of plants. A total of 80 DNA samples was analyzed. The primers ITS86F ( $5^{\prime}$

GTGAATCATCGAATCTTTGAA 3') [33] and ITS4 (5' TCCTCCGCTTATTGATATGC 3') were used to amplify the complete fungal ITS2 region (around $300 \mathrm{bp)} \mathrm{[34].} \mathrm{Illumina} \mathrm{sequencing} \mathrm{primer} \mathrm{sequences} \mathrm{were}$ attached to their $5^{\prime}$ ends.

PCRs were carried out in a final volume of $25 \mu \mathrm{L}$, containing $12.5 \mu \mathrm{L}$ of Supreme NZYTaq 2x Green Master Mix (NZYTech, Lisboa, Portugal), $0.5 \mu \mathrm{M}$ of the primers, $2.5 \mu \mathrm{L}$ of template DNA and ultrapure water up to $25 \mu \mathrm{L}$. The following PCR protocol was used: initial denaturation at $95^{\circ} \mathrm{C}$ for $5 \mathrm{~min}$, followed by 35 cycles of $95^{\circ} \mathrm{C}$ for $30 \mathrm{~s}, 49^{\circ} \mathrm{C}$ for $30 \mathrm{~s}, 72^{\circ} \mathrm{C}$ for $30 \mathrm{~s}$, and a final extension step at $72{ }^{\circ} \mathrm{C}$ for 10 minutes. In a second PCR round, the oligonucleotide indices were attached with identical conditions. However, only five cycles and $60^{\circ} \mathrm{C}$ as the annealing temperature was used for a schematic overview of the library preparation process. Contamination during library preparation in every PCR round was checked by including a negative control that contained no DNA. Positive control consisted in DNA of a grapevine wood sample previously evaluated by ITS2 HTAS was also included [18]. Library size was verified in $2 \%$ agarose gels stained with GreenSafe (NZYTech, Lisboa, Portugal). Libraries were purified using the MagBind RXNPure Plus magnetic beads (Omega Biotek, Norcross, GA, USA), and then pooled in equimolar 
amounts according to the quantification data provided by the Qubit dsDNA HS Assay (Thermo Fisher Scientific, Waltham, USA). The pool was sequenced in a MiSeq PE300 run (Illumina, San Diego, USA). Control samples were sequenced to evaluate potential contaminations of the process.

Data analysis was done as described by Martínez-Diz et al. [18] using clustering in SCATA (https://scata.mykopat.slu.se/). The OTU table, metadata and taxonomic classifications used in this study have been deposited in figshare (ID: 125710). HTAS data have been deposited in GenBank/NCBI under BioProject Acc. No. PRJNA776141.

\subsection{Fungal diversity, taxonomy distribution and statistical analysis}

Alpha-diversity was calculated by analyzing the Chao1 richness and Shannon diversity in Phyloseq package. Differences in fungal alpha-diversity among stocks and nursery stages were inferred by multiple mean comparisons using Tukey's honestly significant difference range test $(P \leq 0.05)$. PERMANOVA was used to infer which OTUs significantly differed in abundance among experimental factors after Bonferroni corrections. The relationship in OTUs composition among samples was investigated by calculating Bray Curtis metrics and visualized in PCoA plots. Good's coverage values and rarefaction curves were also calculated. All diversity analyses were made using MicrobiomeAnalyst [35]. Persistent and transient microbiota were inferred using TIME [36]. Persistent fungal microbiota was defined as those taxa observed in $20 \%$ or more of the sampling moments, but with at least $90 \%$ of those observations being consecutive [37]. Transient fungal microbiota was defined as those taxa observed in at least $60 \%$ of the samples, but with at most $75 \%$ of those observations being consecutive [37].

The identification of fungal taxa that differed in relative abundance among sampling moments was performed by computing the Linear Discriminant Analysis Effect Size (LEfSe) algorithm in MicrobiomeAnalyst. Linear Discriminant Analysis (LDA) threshold score was set up at 1.0 and Wilcoxon $p$-value at 0.05 . The results are displayed in a dot plot. The fungal OTUs shared among sampling moments were visualized by a Venn-diagram analysis (https://bioinformatics.psb.ugent.be/webtools/Venn/). Correlation networks were computed with the SparCC algorithm to identify potential interactions between fungal genera that could represent parasitic, commensal, mutualistic or competitive relationships using MicrobiomeAnalyst. $P$-value threshold was set up at 0.05 with 120 permutations, and the correlation threshold at 0.6 .

Heatmaps were employed to visualize the abundances of GTD fungi in each sampling moment using MicrobiomeAnalyst, with Euclidean as distance measure and Ward as clustering algorithm. ANOVA with log transforms was performed to compare the percentage of abundance of each fungal genus associated with GTDs among sampling moments. Normality of residuals was checked by Shapiro-Wilk's test and homogeneity of the variance by Levene's test. Means were compared using Tukey's test ( $P \leq$ 0.05). For taxonomic identification of Cadophora sp. at species level, the most abundant sequence was selected as an OTU's representative sequence and blasted into the National Center for Biotechnology Information (NCBI). 


\subsection{Functional prediction of fungal communities}

The function of fungal communities in the four sampling moments in both rootstocks was assessed using FUNGuild v1.0 [38]. Three trophic modes were considered, saprotrophs pathotrophs and symbiotrophs. A total of 8 guilds were classified within each trophic mode: ectomycorrhizal fungi, lichenized fungi, fungal endophytes, wood saprotrophs, dung saprotrophs, soil saprotrophs, undefined saprotroph and plant pathogen. Fungal database was used to assign three confidence ranks, namely "highly probable", "probable", and "possible", and. "Unassigned" rank was used for OTUs that not match taxa in the database. The effect of sampling moments on the relative abundance of OTUs was assessed by ANOVA test using Statistix 10 software (Analytical Software). Tukey's test was used to compare transformed data means $(P=0.05)$.

\subsection{Droplet digital PCR assay}

In order to quantify $C$. Iuteo-olivacea inoculum, droplet digital PCR analyses were performed with the DNA extracted from the rootstock wood using the specific primers and probe assay that target the beta-tubulin region [39]. Reactions consisted of $750 \mathrm{nM}$ of each primer, 1x Supermix for Probes (Bio-Rad), $250 \mathrm{nM}$ of the probe and $2 \mu \mathrm{L}$ DNA, for a total volume of $20 \mu \mathrm{l}$. Droplet were generated using the Bio-Rad QX200 ${ }^{\mathrm{TM}}$ droplet generator using the total reaction volume per sample and $70 \mu \mathrm{l}$ of QX200 ${ }^{\mathrm{TM}}$ droplet generation oil. PCR runs were completed in the $\mathrm{C} 1000$ touch thermal cycler (Bio-Rad) using the following PCR thermal cycling conditions: initial heating at $95^{\circ} \mathrm{C}$ for $10 \mathrm{~min}$, followed by 40 cycles of denaturation at $94^{\circ} \mathrm{C}$ for 30 $\mathrm{s}$, and annealing at $55^{\circ} \mathrm{C}$ for $60 \mathrm{~s}$ and a final incubation of $10 \mathrm{~min}$ at $98^{\circ} \mathrm{C}$. PCR plates were transferred into the Bio-Rad QX200 ${ }^{\mathrm{TM}}$ droplet reader and reads were analyzed using QuantaSoft ${ }^{\mathrm{TM}}$ software (BioRad). DNA of $C$. luteo-olivacea isolate BV-0577 was used as a template. The threshold was set manually at 3,000 using two positive controls containing DNA extracted from a pure culture of $C$. luteo-olivacea isolate BV-0577 and DNA of a grapevine wood sample tested positive to $C$. luteo-olivacea by ITS HTAS. A non-template control (NTC) reaction (water) was also included in the analyses. All samples were run by ddPCR in triplicate. According to Bio-Rad recommendation (https://www.biorad.com/webroot/web/pdf/lsr/literature/Bulletin_6407.pdf), wells with less than three positive droplets

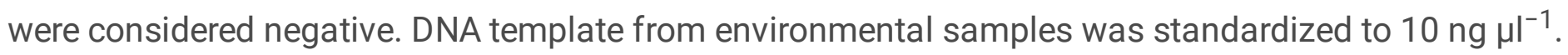

\subsection{Statistical analysis}

Values from the $C$. Iuteo-olivacea number of reads were transformed by $\log (n / N * 1000+1)$, where $n$ was the number of reads detected on each sample and $\mathrm{N}$ was the total number of reads detected. DNA concentration in copies per $\mu$ l was log transformed prior to analysis. Differences in HTAS abundance and ddPCR copy number were determined among the sampling moments using a one-way ANOVA test using Statistix 10 software. Tukey's honestly significant difference test was used to compare data means $(P=0.05)$. Correlation analysis between both HTAS and ddPCR transformed datasets was performed using the corrr package in $\mathrm{R}$ version 3.5 ( $\mathrm{R}$ Core Team, 2021).

\section{Results}




\subsection{Sequencing depth and community diversity}

After paired-end alignments, quality filtering and deletion of chimeras, singletons, a total of $8,665,871$ fungal ITS2 sequences were generated from 78 samples (two samples were removed from the analysis due to the low number of reads), and assigned to 376 fungal operational taxonomic units (OTUs) (Table S1).

Nine fungal genera were identified in the negative control. These sequences were removed from the abundance of that OTU in the experimental samples [40]. According to the Good's coverage values, $96.9 \%$ of the total species richness were accounted for in fungal communities (Table S2). All diversity was captured with an adequate sequencing depth (Fig. S1). Chao1 richness estimator ranged from 27 to 59.5 , and Shannon diversity estimator ranged from 1.32 to 3.05 (Table S2).

\subsection{Effect of nursery stages on diversity and community membership}

Alpha-diversity of fungal communities in both grapevine rootstocks wood samples did not differ significantly between plant stocks (Table 1), thus the data of both stocks for each rootstock were combined for analyses. In general, the alpha-diversity of fungal communities differed among sampling moments for both rootstocks $(P<0.05)$ (Table 1; Fig. 1). Sampling moment did not predict Shannon diversity in $110 \mathrm{R}$ rootstock (Table 1). In $110 \mathrm{R}$, taxa richness (Chao1) was lower in sampling moments 1 and 4 compared to sampling moments 2 and 3 (Fig. 1). In 41 B, taxa richness was lower in sampling moment 4 compared to the other sampling moments, while taxa richness and evenness (Shannon) provided the lowest values for sampling moments 2 and 4, although no significant differences were found between sampling moments 1 and 4 (Fig. 1). Principal coordinates analysis (PCoA) of Bray Curtis data demonstrated that sampling moment was the primary source of beta-diversity in both $110 \mathrm{R}\left(R^{2}=\right.$ $0.39, P<0.001)$ and $41 \mathrm{~B}\left(R^{2}=0.56, P<0.001\right)$ rootstocks (Fig. 2$)$.

Ascomycota dominated the fungal phyla across sampling moments in both rootstocks, with percentages of abundances ranging from $86 \%$ (sampling moment 1) to $98 \%$ (sampling moment 2) in $110 \mathrm{R}$, and from $76 \%$ (sampling moment 1) to $93 \%$ (sampling moment 4) in $41 \mathrm{~B}$ (Fig. S2). In $110 \mathrm{R}$ rootstock, the lowest values of fungal richness and diversity were obtained in sampling moments 1 (46 \pm 9.1$)$ and $3(2.2 \pm 0.3)$, respectively (Fig. 1). The most abundant families were Phaeosphaeriaceae (14.3\%) and Cladosporiaceae $(11.3 \%)$ in sampling moment 1 , Trichocomaceae $(29.4 \%)$ and Cladosporiaceae $(12.2 \%)$ in sampling moment 2, Incertae sedis 31 (15.6\%) and Ploettnerulaceae (15.1\%) in sampling moment 3, and Togniniaceae (9.1\%) and Bionectriaceae (9.0\%) in sampling moment 4 (Fig. 3). The core communities were dominated by Cladosporiaceae, Dothioraceae, Nectriaceae, Pleosporaceae, Ploettnerulaceae and Trichocomaceae. The persistent community was composed of an unknown family within the Sordariales and Incertae sedis 13 family, while the transient community was composed of Bulleribasidiaceae, Ceratobasidicaceae, Filobasidiaceae, Helotiaceae, Herpotrichiellaceae, Schizophyllaceae, Slcerotiniaceae 
and Xylariaceae. Seven (2.4\%) and twenty (6.8\%) genera were defined as persistent and transient taxa, respectively (Table S3).

In $41 \mathrm{~B}$ rootstock, the lowest value of fungal richness was obtained in sampling moment $4(37 \pm 7.3)$, while the lowest values of fungal diversity were obtained in sampling moments $2(2.2 \pm 0.4)$ and $4(2.2 \pm$ 0.3), respectively (Fig. 1). The most abundant families were Cladosporiaceae (18.5\%) and Pleosporaceae $(15.0 \%)$ in sampling moment 1 , Cladosporiaceae (33.7\%) and Trichocomaceae (19.1\%) in sampling moment 2, Incertae_sedis_3 (14.7\%) and Ploettnerulaceae (11.6\%) in sampling moment 3 , and Pleosporaceae (13.1\%) and Botryosphaeriaceae (9.7\%) in sampling moment 4 (Fig. 3). The core communities were dominated by Botrosphaeriaceae, Cladosporiaceae, Dothioraceae, Incertae sedis 3 and 13, Leptosphaeriaceae, Nectriaceae, Phaeosphaeriaceae, Pleosporaceae, Ploettnerulaceae and Trichocomaceae families. The persistent community was composed of unknown families within the orders Tremellalles and Sordariales, Bulleribasidiaceae, Schizophyllaceae and Trichosporonaceae families. The transient community was composed of Chaetothyriaceae, Helotiaceae, Incertae sedis 25 and 31, Lophiostomataceae, Sarocladiaceae and Xylariaceae families. Nine (3.3\%) and fourteen (5.2\%) genera were defined as persistent and transient taxa, respectively (Table S3).

\subsection{Nursery stages specific and shared fungal assemblages}

The percentage of shared fungal OTUs among the four sampling moments were similar in both rootstocks.: $24.8 \%(110 \mathrm{R})$ and $21.4 \%$ (41 B) (Fig. S3). Core taxa with more than 50\% prevalence were composed by Cadophora (94.6\%), Cladosporium (86.6\%), Penicillium (78.3\%), Eucasphaeria (72.9\%), Paraphoma (64.8\%), Fusarium (64.8\%) and Alternaria (56.7\%) in 110 R rootstock, and Alternaria (94.8\%), Cladosporium (89.7\%), Acremonium (71.8\%), Cadophora (61.5\%), Penicillium (53.8\%) and Aureobasidium $(51.2 \%)$ in $41 \mathrm{~B}$ rootstock (Fig. S4). Specific OTUs associated with each sampling moment ranged from 6.8 to $14.6 \%(110 \mathrm{R})$, and from 8.1 to $15.5 \%(41 \mathrm{~B})$. The OTUs that were unique in each sampling moment for each rootstock are shown in Table S4. Four, one and fifteen unique taxa were identified in both rootstocks in sampling moments 1,3 and 4, respectively. No unique fungal taxa were present in both rootstocks in sampling moment 2 (Table S4).

The top 15 fungal clades in the grapevine inner tissues detected by the LEfSe analysis which discriminated the fungal communities among sampling moments in $110 \mathrm{R}$ and $41 \mathrm{~B}$ rootstocks are shown in Fig. 4. The sampling moment 4 showed higher number of differentially abundant fungal clades ( 5 and 7 in $110 \mathrm{R}$ and $41 \mathrm{~B}$, respectively). In the sampling moment 1, the dominant fungal genus in both rootstocks was Tremellomycetes. In the sampling moment 2, the dominant fungal genera were Penicillium (110 R) and Cladosporium (41 B). In the sampling moment 3, the dominant fungal genera were Eucasphaeria (110 R) and Acremonium (41 B), while Phaeoacremonium (110 R) and Clonostachys (41 B) represented the dominant fungal genera in the sampling moment 4 (Fig. 4). In $110 \mathrm{R}$ rootstock, 49 interactions were identified between fungal taxa, 34 positives and 15 negatives (Fig. 5; Table S5).

Curvibasidium genus and an unknown genus within the Sordariales order established the highest number 
of correlations $(\mathrm{n}=9)$ with other fungal taxa. In $41 \mathrm{~B}$ rootstock, 80 interactions were identified between fungal taxa, 54 positives and 26 negatives (Fig. 5; Table S6). Rhizoctonia genus established the highest number of correlations $(n=15)$ with other fungal taxa.

\subsection{Nursery propagation stages affect fungal functionality}

There were significant differences in the relative proportion of fungal functions within each sampling moment for both rootstocks $(P<0.05)$ (Fig. 6; Table S7). The trophic mode in sampling moment 1 was dominated by symbiotrophs which accounted for $48.0 \%$ and $47.9 \%$ of the total OTUs in $110 \mathrm{R}$ and $41 \mathrm{~B}$ rootstocks, respectively, but with no significant differences with saprotrophs. In the remaining sampling moments, saprotrophs were found in higher proportions compared to the other groups (Fig. 6; Table S7). Regarding the pathotrophs, the relative proportion was higher in sampling moment $4(14.1 \%$ in $110 \mathrm{R}$ and $15.4 \%$ in $41 \mathrm{~B})$ and lower in sampling moment $2(2.9 \%$ in $110 \mathrm{R}$ and $1.8 \%$ in $41 \mathrm{~B})$ for both rootstocks.

The relative abundances of endophytes were higher in sampling moment 2 in $110 \mathrm{R}(43.1 \%)$ and sampling moment 1 in $41 \mathrm{~B}(49.8 \%)$, and lower in sampling moment 4 in both rootstocks $(27.4$ and $26.1 \%$, respectively) (Table S8). The relative abundances of wood saprotrophs were higher in sampling moments 1 (43\%) and 2 (42.5\%) in $110 \mathrm{R}$, and in sampling moment 2 in $41 \mathrm{~B}(47.1 \%)$, and lower in sampling moment 4 in both rootstocks (18.0 and $22.2 \%$, respectively). The relative abundances of soil saprotrophs in sampling moment 4 in $110 \mathrm{R}(11.4 \%)$, and in sampling moments $3(4.7 \%)$ and $4(6.7 \%)$ in $41 \mathrm{~B}$ were significantly higher than in the other sampling moments $(P<0.05)$ (Table S8). Undefined saprotrophs were significantly less abundant in sampling moments $1(9.0 \%)$ and $2(9.5 \%)$ in $110 \mathrm{R}$, and in sampling moment $1(9.1 \%)$ in $41 \mathrm{~B}(P<0.05)$. Plant pathogens were detected in higher abundances in sampling moment 4 in both rootstocks (12.5\% in $110 \mathrm{R}$ and $14.1 \%$ in $41 \mathrm{~B})$, with no significant differences with sampling moment 3 ( $P>0.05)$. Lichenized fungi were only found in sampling moments 1 $(3 \%)$ and $3(2 \%)$ in $110 \mathrm{R}$, and in sampling moment 2 in $41 \mathrm{~B}(0.4 \%)$. In both rootstocks, ectomycorrhizal and dung saprotrophs were only identified in sampling moment 4 (Table S8).

\subsection{Shifts in fungal trunk pathogens infection throughout the propagation process}

Among the identified fungal taxa in both rootstocks, 8 genera were associated with GTDs: Cadophora, Dactylonectria, Diaporthe, Diplodia, Ilyonectria, Neofusicoccum, Phaeoacremonium and Phaeomoniella. In both rootstocks, the abundances of the Petri disease pathogens Phaeoacremonium and Phaeomoniella were higher in sampling moment 4, while the abundances of Cadophora and Neofusicoccum were higher in sampling moments 3 and 2, respectively (Fig. 7). In 110 R, the abundances of the black-foot pathogens Ilyonectria and Dactylonectria were higher in sampling moment 2, while the abundances of Diplodia and Diaporthe were higher in sampling moment 2. In $41 \mathrm{~B}$, the abundances of Ilyonectria, Diaporthe and Diplodia were higher in sampling moment 4, while the abundance of Dactyonectria was higher in sampling moment 1 (Fig. 7). 


\subsection{Correlation between Cadophora luteo-olivacea sequencing reads and droplet digital PCR}

The OTUs' representative sequence of Cadophora sp. had 100\% identity with C. luteo-olivacea CBS 141.41 (GenBank Accession No. NR165945.1). Cadophora luteo-olivacea abundances significantly differed among sampling moments, ranging from 65 to 95,891 reads in $110 \mathrm{R}$, and from 45 to 21,574 reads in $41 \mathrm{~B}$ (Fig. 8; Table S9). In both $110 \mathrm{R}$ and $41 \mathrm{~B}$ rootstocks, the sampling moment factor had a significant effect on $C$. luteo-olivacea abundances ( $P<0.01$; Fig. 8). In $110 \mathrm{R}$, the abundance of $C$. luteoolivacea was significantly higher in the sampling moment 3 compared with the sampling moments 1 and $4(P<0.01)$. No significant differences were found between sampling moments 2 and 3 , and between sampling moments 2 and 4 ( $P>0.05$; Fig. 8). In $41 \mathrm{~B}$, the abundance of $C$. Iuteo-olivacea was significantly higher in the sampling moments 2,3 and 4 compared with the sampling moment $1(P<0.01$; Fig. 8$)$.

DNA of $C$. luteo-olivacea was detected in all samples analyzed by ddPCR (Table S9). Of those, 76 samples (97.4\%) had at least three positive droplets and were called a sample positive (Table S9). Fungal concentrations in these positive samples ranged from 4.5 to 177 copies/ $\mu \mathrm{l}$ in $110 \mathrm{R}$ and from 4 to 101.5 copies/ $\mu \mathrm{l}$ in $41 \mathrm{~B}$ (Table S9). Positive control containing DNA from grapevine wood was positive to $C$. luteo-olivacea. No positive droplets occurred using NTC (Fig S5). In both rootstocks, the sampling moment factor had a significant effect on $C$. Iuteo-olivacea DNA concentration detected $(P<0.01 ;$ Fig. 8$)$. In $110 \mathrm{R}$, the concentration of DNA detected was significantly higher in the sampling moments 2 and 3 compared with the other sampling moments (Fig. 8). In $41 \mathrm{~B}$, the concentration of DNA detected was significantly higher in the sampling moment 3 compared with the sampling moments 1 and $4(P<0.01)$. No significant differences were found between sampling moments 2 and 3 , and between sampling moments 2 and 4 ( $P>0.05$; Fig. 8).

The analysis showed a positive significant correlation between the number of OTUs and the $C$. luteoolivacea DNA quantified using the ddPCR approach $(P<0.01$, Spearman correlation coefficients $=0.78$ in $110 \mathrm{R}$ and 0.77 in $41 \mathrm{~B}$ ) (Fig S6).

\section{Discussion}

In this study, we examined the temporal dynamics of the fungal microbiome in grapevine rootstocks throughout four stages of the propagation process, using a non-destructive method. To date, research on grapevine microbiome has predominantly focused on the scion cultivar, as it is the visible half-part of the vine and produces the fruit. However, more than $80 \%$ of the vineyards worldwide are currently grafted onto rootstocks [41], which have a relevant influence on crop yield, grape quality and give protection against pathogens and pests [2].

The fungal microbiome in both rootstocks analysed in this study, $110 \mathrm{R}$ and $41 \mathrm{~B}$, was dominated by the Ascomycota phylum throughout the propagation process. This result is consistent with previous studies aimed to explore the grapevine endophytic fungal communities by HTAS approach [14-18, 42-49]. 
A total of 376 OTUs were detected in our study, ranging from 154 to 172 OTUs, and from 241 to 250 OTUs in $110 \mathrm{R}$ and $41 \mathrm{~B}$ rootstocks, respectively. The high number of OTUs found in this study differs from results obtained in previous grapevine research conducted by culture dependent approaches. In Switzerland, Casieri et al. [50] identified only 66 OTUs occurring in the wood of 1 -year-old $V$. vinifera grafted plants, whereas Hofstetter et al. [51] isolated 85 fungal species from healthy nursery planting material. In France, Bruez et al. [52] identified 48 OTUs from healthy wood tissues of the trunk disease esca leaf-asymptomatic and symptomatic vines. In this regard, Kraus et al. [11] identified 86 OTUs in healthy grapevine branches with different ages (from 2-month to 8-year-old) in Germany, although it should be noted that the OTU accumulation curves produced for each branch age hardly started to saturate, suggesting that the number of OTUs would probably increase with major number of samples. A comparative study that aimed to investigate changes in the potentially active fungal communities of internal grapevine wood after hot-water treatment (HWT) in nursery material, revealed that HTAS-based procedure was superior to traditional isolation in detection and identification of fungal communities [15].

The core microbiome was composed by the genera Cadophora, Cladosporium, Penicillium and Alternaria in both rootstocks, together with Eucasphaeria, Paraphoma and Fusarium in $110 \mathrm{R}$, and Acremonium and Aureobasidium in $41 \mathrm{~B}$. These results are in line with recent studies focused on exploring the interior of grapevine wood. The ubiquitous, fast-growing fungi Cladosporium, Alternaria and Aureobasidium were previously found dominating the fungal community in the xylem vessels of healthy grapevine branches for all ages in Germany [11], as well as in the grapevine sap of shoots under high Pierce's disease pressure throughout the growing season in California [42]. In addition, these fungal genera were frequently found colonizing the grapevine wood after pruning in Spain [18]. Moreover, Cladosporium was found as the dominant fungal taxa inhabiting several biocompartments of the grapevine endosphere in California [43]. The fungal genera Acremonium, Fusarium and Penicillium were also found with high prevalence on grapevine nursery plants, even after HWT, in Spain and Czech Republic [15]. Regarding Eucasphaeria, fungal species belonging to this genus were isolated from grapevine nursey plants in Switzerland [51], and interestingly, the specie E. capensis was isolated from a zone of dark discoloration from wood of rootstock in Germany, although its pathogenic ability on grapevine remained unknown [53]. Recently, Eucasphaeria was found colonizing grapevine pruning wounds in Spain [18]. Also, fungi belonging to Paraphoma genus, a Phoma-like fungi [54], were previously found inhabiting both escasymptomatic and asymptomatic vines, as well as grapevine nursery plants in Switzerland [51]. The role of Aureobasidium, in particular the species A. pullulans, as a potential biocontrol agent of fungal trunk pathogens of grapevine has been demonstrated in vitro [55] and in planta [56]. Species of this genus have been shown to prevail in the core microbiome of grapevine in recent studies $[14,18,42,44]$. Several studies have already revealed the presence of Cadophora, associated with Petri disease and esca on young and mature grapevines, respectively, inhabiting the interior of the vine wood in nursery stock [15, $23,39,50,51,57]$, during the propagation stages in nurseries [23], and in mature vines $[11,14,18,20]$.

The fungal genus Neofusicoccum was found as a persistent taxon in both rootstocks, which confirms this genus as a primary settler of grapevine vascular tissues. This genus belongs to the Botryosphaeriaceae family and is considered one of the most virulent fungal genera associated with the 
trunk disease Botryosphaeria dieback [58, 59], being Neofusicoccum parvum the most common Neofusicoccum species isolated from grapevine worldwide [60]. The role of rootstock mother vines as a primary source of Neofusicoccum spp. has been well-documented by Aroca et al. [28]. Neofusicoccum spp. are spread by the dispersion of airborne spores that penetrate into mother plants and mature vines through the pruning wounds [20]. Previous research has found Neofusicoccum spp. inhabiting rootstocks from nursery material at different stages of the propagation process $[15,51,60,61]$.

Results obtained in our study showed that taxa richness and fungal diversity in the vascular system of the grapevine $110 \mathrm{R}$ and $41 \mathrm{~B}$ rootstocks was, in general, decreasing throughout the propagation process. This result was surprising since we expected an increase of fungal diversity after the root development stage in the nursery field where multiple interactions between the plant and soil microorganisms can occur. This could be partially attributed to the enhancing microbial interaction with planting material in nursery practices such a hydration and callusing. For instance, hydration stage has been pointed out as a potential source of cross contamination by microorganisms [62].

Fungal functionality analysis showed that the relative abundance of endophytes decreased throughout the propagation process, while the abundance of plant pathogens increased towards the last stage and before selling the plant to the grower. In fact, we identified 8 genera associated with GTDs. Among them, it should be pointed out that the relative abundance of genera associated with black-foot, such as Ilyonectria in $110 \mathrm{R}$, as well as genera associated with Petri disease, such as Phaeomoniella and Phaeoacremonium in both rootstocks, increased significantly after the root development in the nursery field. The soilborne black-foot pathogens are commonly found in nursery field soils [63], and their capacity to infect grafted grapevine once planted in the field nursery is well-documented [64, 65]. A survey carried out in Spanish nurseries highlighted the relative higher abundance of black-foot fungi after one growing season in field nurseries compared to their abundances in hydration tanks and callusing rooms [65]. Petri disease pathogens can spend part of their life cycle in vineyard soils, which allow them to infect young vines through the roots [66]. Wounds made during the nursery process can also be an important point of entry of GTD fungi, such as Petri disease pathogens [4] or fungi associated with Botryosphaeria [67] and Phomopsis [28] diebacks. This is in line with the results of our study, which resulted in high detection of GTD fungi such as Neofusicoccum spp. (Botryosphaeria dieback) and Diaporthe spp. (Phomopsis dieback) in $110 \mathrm{R}$, and Neofusicoccum spp. in $41 \mathrm{~B}$, during the early stage of the propagation process. Surprisingly, correlation network analysis resulted in low level of connectivity among GTD fungi in all stages of the propagation process, even though co-infections among these pathogens is common in vascular tissues of young vines $[68,69]$.

The results obtained from our ddPCR assay indicated that $C$. luteo-olivacea was present in $97 \%$ of the plant material analyzed, with fungal concentrations similar to those found by Maldonado-González et al. [39]. The abundance and DNA quantity of the fungus was higher in sampling moments 2 and 3 , after hydration and callusing (following grafting) stages, respectively. Previous research showed that $C$. luteoolivacea inoculum is commonly found in hydration tanks and washings from grafting tools in Spanish nurseries [23]. Comparison of both HTAS and ddPCR techniques resulted in positive correlations between 
sequence reads and DNA quantification in both $110 \mathrm{R}$ and $41 \mathrm{~B}$ rootstocks. HTAS is a robust and powerful approach to study microbial populations, but quantitative significance of its results is often debated [70]. In contrast, ddPCR has recently emerged as a powerful, reliable and accurate technique for detection and quantification of microorganisms, and its success for absolute quantification of GTD fungi from environmental samples has been denoted [39, 71, 72]. Recent efforts have been made to validate the results of HTAS data by comparison with relative or absolute quantification approaches in different environments [73, 74]. For instance, a significant positive correlation between sequencing reads and DNA relative abundance of black-foot pathogens was observed in vineyard soil samples in Spain [29].

Given the results of this study and the lack of authorized effective chemicals against GTD fungi in grapevine nurseries, alternative strategies such as biological control with antagonistic microorganisms, HWT, the use of tolerant rootstocks or biofumigation should be implemented to minimize GTD infection throughout the propagation processes. An integrated management strategy is strongly recommended, including HWT at $50[75]$ or $53^{\circ} \mathrm{C}[15,76]$ for $30 \mathrm{~min}$, biocontrol with Trichoderma atroviride SC 1 in hydration tanks [77], the use of rootstocks with high tolerance to GTD vascular fungi [78], and biofumigation with white mustard in grapevine nursery fields [79].

\section{Declarations}

\section{Acknowledgments}

D. Gramaje was supported by the Ramón y Cajal Program, Spanish Government (RYC-2017-23098). We thank M. Maldonado-González and M. Andrés-Sodupe for the technical support.

\section{Author's contributions}

DG and PR designed the experiments. DG and RB collected the samples. DG, MS, AE, JV, MJC analyzed the data and created the graphs, DG and PR wrote the paper. All authors discussed the results, read, and approved the final version of the manuscript.

\section{Funding}

This work has been partially supported by Ministerstvo Školství, Mládeže a Tělovýchovy (CZ.02.1.01./0.0/0.0/16_017/0002334) and the “José Castillejo" program (CAS 18/00065).

\section{Availability of data and materials}

The OTU table, metadata and taxonomic classifications used in this study have been deposited in figshare (ID: 125710). HTAS data have been deposited in GenBank/NCBI under BioProject Acc. No. PRJNA776141.

\section{References}


1. Mudge K, Janick J, Scofield S, Goldschmidt EE. A history of grafting. Hortic. Rev. 2009;35437-493. https://doi.org/10.1002/9780470593776.ch9.

2. Marín D, Armengol J, Carbonell-Bejerano P, Escalona J, Gramaje D, Hernández-Montes E, Intrigliolo D, Martínez-Zapater J, Medrano H, Mirás-Avalos J, Palomares-Rius J, Romero-Azorín P, Savé R, Santesteban L, de Herralde F. Challenges of viticulture adaptation to global change: tackling the issue from the roots. Aust J Grape Wine Res. 2021;27:8-25. https://doi.org/10.1111/ajgw.12463.

3. Waite, H., Whitelaw-Weckert, M., Torley. Grapevine propagation: principles and methods for the production of high-quality grapevine planting material. New Zealand J. Crop Horticult. Sci. 2015; 144.16. https://doi.org/10.1080/01140671.2014.978340

4. Gramaje D, Armengol J. Fungal trunk pathogens in the grapevine propagation process: potential inoculum sources, detection, identification, and management strategies. Plant Dis. 2011;95(9):10401055. https://doi.org/10.1094/PDIS-01-11-0025.

5. Bokulich NA, Thorngate JH, Richardson PM, Mills DA. Microbial biogeography of wine grapes is conditioned by cultivar, vintage, and climate. Proc Natl Acad Sci USA. 2014;111(1):E139-E148. https://doi.org/10.1073/pnas.1317377110.

6. Perazzolli M, Antonielli L, Storari M, Puopolo G, Pancher M, Giovannini O, Pindo M, Pertot I. Resilience of the natural phyllosphere microbiota of the grapevine to chemical and biological pesticides. Appl. Environm. Microbiol. 2014; 80:3585-3596. https://doi.org/ 10.1128/AEM.00415-14.

7. Zarraonaindia I, Owens SM, Weisenhorn P, West K, Hampton-Marcell J, Lax S, Bokulich NA, Mills DA, Martin G, Taghavi S, van der Lelie D, Gilbert JA. The soil microbiome influences grapevine-associated microbiota. mBio 2015;6(2):e02527-14. https://doi.org/10.1128/mBio.02527-14.

8. West ER, Cother EJ, Steel CC, Ash GJ. The characterization and diversity of bacterial endophytes of grapevine. Can. J. Microbiol. 2010; 56:209-216. https://doi.org/10.1139/W10-004.

9. Compant S, Mitter B, Colli-Mull JG, Gangl H, Sessitsch A. Endophytes of grapevine flowers, berries, and seeds: identification of cultivable bacteria, comparison with other plant parts, and visualization of niches of colonization. Microb. Ecol. 2011;62:188-197. https://doi.org/10.1007/s00248-0119883-y.

10. Baldan, E., Nigris, S., Populin, F., Zottini, M., Squartini, A., Baldan, B. Identification of culturable bacterial endophyte community isolated from tissues of Vitis vinifera "Glera". Plant Biosyst. 2014; 148:508-516. https://doi.org/10.1080/11263504.2014.916364.

11. Kraus $\mathrm{C}$, Voegele RT, Fischer M. temporal development of the culturable, endophytic fungal community in healthy grapevine branches and occurrence of GTD-associated fungi. Microb Ecol. 2019;77(4):866-876. https://doi.org/10.1007/s00248-018-1280-3.

12. Faist $H$, Keller $A$, Hentschel $U$, Deeken R. Grapevine (Vitis vinifera) crown galls host distinct microbiota. Appl Environ Microbiol. 2016;82:5542-5552. https://doi.org/10.1128/AEM.01131-16.

13. Deyett E, Roper MC, Ruegger P, Yang J, Borneman J, Rolshausen PE. Microbial landscape of the grapevine endosphere in the context of Pierce's disease. Phytobiomes 2017;1: 138-149. https://doi.org/10.1094/PBIOMES-08-17-0033-R. 
14. Dissanayake AJ, Purahong W, Wubet T, Hyde KD, Zhang W, Xu H, Zhang G, Fu C, Liu M, Xing Q, Li X, Yan, J. Direct comparison of culture-dependent and culture-independent molecular approaches reveal the diversity of fungal endophytic communities in stems of grapevine (Vitis vinifera). Fungal Divers. 2018;90:85-107. https://doi.org/10.1007/s13225-018-0399-3.

15. Eichmeier A, Pečenka J, Peňázová E, Baránek M, Català-García S, León M, Armengol J, Gramaje D. High-throughput amplicon sequencing-based analysis of active fungal communities inhabiting grapevine after hot-water treatments reveals unexpectedly high fungal diversity. Fungal Ecol. 2018;36:26-38. https://doi.org/10.1016/j.funeco.2018.07.011.

16. Bruez E, Vallance J, Gautier A, Laval V, Compant S, Maurer W, Sessitsch A, Lebrun MH, Rey P. Major changes in grapevine wood microbiota are associated with the onset of esca, a devastating trunk disease. Environ. Microbiol. 2020;22:5189-5206. https://doi.org/10.1111/1462-2920.15180.

17. Bruez E, Larignon P, Bertsch C, Robert-Siegwald G, Lebrun M.H., Rey P, Fontaine F. Impacts of sodium arsenite on wood microbiota of Esca-diseased grapevines. J. Fungi 2021;7:498. https://doi.org/10.3390/jof7070498.

18. Martínez-Diz MP, Eichmeier A, Spetik M, Bujanda R, Díaz-Fernández A, Díaz-Losada E, Gramaje D. Grapevine pruning time affects natural wound colonization by wood-invading fungi. Fungal Ecol. 2020a;48(100994):1-13. https://doi.org/10.1016/j.funeco.2020.100994.

19. Waite H, May P. The effects of hot water treatment, hydration and order of nursery operations on cuttings of Vitis vinifera cultivars. Phytopathol. Mediterr. 2005;44:144-152.

20. Gramaje D, Úrbez-Torres JR, Sosnowski MR. Managing grapevine trunk diseases with respect to etiology and epidemiology: current strategies and future prospects. Plant Dis. 2018;102(1):12-39. https://doi.org/10.1094/PDIS-04-17-0512-FE.

21. Berlanas C, Ojeda S, López-Manzanares B, Andrés-Sodupe M, Bujanda R, Martínez-Diz MP, DíazLosada E, Gramaje D. Occurrence and diversity of black-foot disease fungi in symptomless grapevine nursery stock in Spain. Plant Dis. 2020;104(1):94-104. https://doi.org/10.1094/PDIS-03-19-0484-RE.

22. Halleen F, Crous PW, Petrini O. Fungi associated with healthy grapevine cuttings in nurseries, with special reference to pathogens involved in the decline of young vines. Aust. Plant Pathol. 2003;32:47-52. https://doi.org/10.1071/AP02062.

23. Gramaje D, Mostert L, Armengol J. Characterization of Cadophora luteo-olivacea and C. melinii isolates obtained from grapevines and environmental samples from grapevine nurseries in Spain. Phytopathol Mediterr. 2011;50(4):112-126. https://doi.org/10.14601/Phytopathol_Mediterr-8723.

24. Úrbez-Torres JR, Haag P, Bowen P, O’Gorman DT. Grapevine trunk diseases in British Columbia: incidence and characterization of the fungal pathogens associated with esca and Petri diseases of grapevine. Plant Dis. 2014;98(4):469-482. https://doi.org/10.1094/PDIS-05-13-0523-RE.

25. Travadon R, Lawrence DP, Rooney-Latham S, Gubler WD, Wilcox WF, Rolshausen PE, Baumgartner K. Cadophora species associated with wood-decay of grapevine in North America. Fungal Biol. 2015;119(1):53-66. https://doi.org/10.1016/j.funbio.2014.11.002. 
26. Held BW, Jurgens JA, Arenz BE, Duncan SM, Farrell RL, Blanchette RA. Environmental factors influencing microbial growth inside the historic expedition huts of Ross Island, Antarctica. Int. Biodeter. Biodegr. 2005; 55:45-53. https://doi.org/10.1016/j.ibiod.2004.06.011.

27. Marchese P, Garzoli L, Young R, Allcock L, Barry F, Tuohy M, Murphy M. Fungi populate deep-sea coral gardens as well as marine sediments in the Irish Atlantic Ocean. Environm. Microbiol. 2021; 23:4168-4184. https://doi.org/10.1111/1462-2920.15560.

28. Aroca Á, Gramaje D, Armengol J, García-Jiménez J, Raposo R. Evaluation of the grapevine nursery propagation process as a source of Phaeoacremonium spp. and Phaeomoniella chlamydospora and occurrence of trunk disease pathogens in rootstock mother vines in Spain. Eur J Plant Pathol. 2010;126:165-174. https://doi.org/10.1007/s10658-009-9530-3.

29. Berlanas C, Berbegal M, Elena G, Laidani M, Cibriain JF, Sagües A, Gramaje D. The fungal and bacterial rhizosphere microbiome associated with grapevine rootstock genotypes in mature and young vineyards. Front Microbiol. 2019;10(1142):1-16. https://doi.org/10.3389/fmicb.2019.01142.

30. Gramaje D, García-Jiménez J, Armengol J. Field evaluation of grapevine rootstocks inoculated with fungi associated with Petri disease and Esca. Am J Enol Vitic. 2010a;61:512-520. https://doi.org/10.5344/ajev.2010.10021.

31. Alaniz S, García-Jiménez J, Abad-Campos P, Armengol J. Susceptibility of grapevine rootstocks to Cylindrocarpon liriodendri and C. macrodidymum. Sci. Hortic. 2010; 125:305-308. https://doi.org/10.1016/j.scienta.2010.04.009.

32. Eguizábal E. Development of a non-destructive method to detected and identify fungal pathogens of grapevine planting material (in Spanish). Master's Thesis. University of La Rioja, Spain. 2018, Publication No. 3382.

33. Turenne CY, Sanche SE, Hoban DJ, Karlowsky JA, Kabani AM. Rapid identification of fungi by using the ITS2 genetic region and an automated fluorescent capillary electrophoresis system. J Clin Microbiol. 1999;37(6):1846-1851. https://doi.org/10.1128/JCM.37.6.1846-1851.1999.

34. White TJ, Bruns T, Lee SH, Taylor JW. Amplification and direct sequencing of fungal ribosomal RNA genes for phy-logenetics. In PCR Protocols: A Guide to Methods and Applications; Innis MA, Gelfand DH, Sninsky JJ, White TJ, Eds.; Academic Press, San Diego, USA. 1990. pp. 315-322. https://doi.org/10.1016/B978-0-12-372180-8.50042-1.

35. Chong J, Liu P, Zhou G, Xia J. Using MicrobiomeAnalyst for comprehensive statistical, functional, and meta-analysis of microbiome data. Nat Protoc. 2020;15:799-821. https://doi.org/10.1038/s41596-019-0264-1.

36. Baksi KD, Kuntal BK, Mande, SS. 'TIME': A web application for obtaining insights into microbial ecology using longitudinal microbiome data. Front. Microb. 2018;9:36. https://doi.org/10.3389/fmicb.2018.00036.

37. Caporaso JC, Lauber CL, Costello EK, Berg-Lyons D, Gonzalez A, Stombaugh J, Knights D, Gajer P, Ravel J, Fierer N, Gordon JI, Knight R. Genome Biol. 2011; 12:R50. 
38. Nguyen NH, Song Z, Bates ST, Branco S, Tedersoo L, Menke J, Schilling JS, Kennedy PG. FUNGuild: an open annotation tool for parsing fungal community datasets by ecological guild. Fungal Ecol. 2016;20:241-248. https://doi.org/10.1016/j.funeco.2015.06.006.

39. Maldonado-González MM, Martínez-Diz MP, Andrés-Sodupe M, Bujanda R, Díaz-Losada E, Gramaje D. Quantification of Cadophora luteo-olivacea from grapevine nursery stock and vineyard soil using droplet digital PCR. Plant Dis. 2020;104(8):2269-2274. https://doi.org/10.1094/PDIS-09-19-2035RE.

40. Nguyen NH, Smith D, Peay K, Kennedy P. Parsing ecological signal from noise in next generation amplicon sequencing. New Phytol. 2015; 205:1389-1393. https://doi.org/10.1111/nph.12923.

41. Ollat N, Peccoux A, Papura D, Esmenjaud D, Marguerit E, Tandonnet JP, Bordenave L, Cookson SJ, Barrieu F, Rossdeutsch L, Lecourt J, Lauvergeat V, Vivin P, Bert PF, Delrot S. Rootstocks as a component of adaptation to environment. Gerós H, Chaves MM, Gil HM, Delrot S, eds. Grapevine in a changing environment (John Wiley:Chichester, England). 2016. pp. 68-108.

42. Deyett $E$, Rolshausen PE. temporal dynamics of the sap microbiome of grapevine under high Pierce's disease pressure. Front Plant Sci. 2019;10(1246):1-15. https://doi.org/10.3389/fpls.2019.01246.

43. Deyett E, Rolshausen PE. Endophytic microbial assemblage in grapevine. FEMS Microbiol Ecol. 2020;9(5):1-11. https://doi.org/10.1093/femsec/fiaa053.

44. Martínez-Diz MP, Andrés-Sodupe M, Bujanda R, Díaz-Losada E, Eichmeier A, Gramaje D. Soil-plant compartments affect fungal microbiome diversity and composition in grapevine. Fungal Ecol. 2019;41:234-244. https://doi.org/10.1016/j.funeco.2019.07.003.

45. Fan Y, Gao L, Chang P, Li Z. Endophytic fungal community in grape is correlated to foliar age and domestication. Ann Microbiol. 2020;70(30):1-8. https://doi.org/10.1186/s13213-020-01574-9.

46. Knapp DG, Lázár A, Molnár A, Vajna B, Karácsony Z, Váczy KZ, Kovács GM. Above-ground parts of white grapevine Vitis vinifera $\mathrm{cv}$. Furmint share core members of the fungal microbiome. Environ Microbiol Rep. 2021;13(4):509-520. https://doi.org/10.1111/1758-2229.12950.

47. Liu D, Howell K. Community succession of the grapevine fungal microbiome in the annual growth cycle. Environ Microbiol. 2021;23(4):1842-1857. https://doi.org/10.1111/1462-2920.15172.

48. Radić T, Likar M, Hančević K, Regvar M, Čarija M, Zdunić G. Root-associated community composition and co-occurrence patterns of fungi in wild grapevine. Fungal Ecol. 2021;50(101034):1-11. https://doi.org/10.1016/j.funeco.2020.101034.

49. Carbone MJ, Alaniz S, Mondino P, Gelabert M, Eichmeier A, Tekielska D, Bujanda R, Gramaje D. Drought influences fungal community dynamics in the grapevine rhizosphere and root microbiome. J. Fungi. 2021;7(9):686. https://doi.org/10.3390/jof7090686.

50. Casieri L, Hofstetter V, Viret O, Gindro K. Fungal communities living in the wood of different cultivars of young Vitis vinifera plants. Phytopathol Mediterr. 2009;48(1):73-83. https://www.jstor.org/stable/10.2307/26463332.

51. Hofstetter V, Buyck B, Croll D, Viret O, Couloux A, Gindro K. What if esca disease of grapevine were not a fungal disease? Fungal Divers. 2012;54:51-67. https://doi.org/10.1007/s13225-012-0171-z. 
52. Bruez E, Vallace J, Gerbore J, Lecomte P, Da Costa J-P., Gerin-Dubrana L, Rey P. Analyses of the temporal dynamics of fungal communities colonizing the healthy wood tissues of esca leafsymptomatic and asymptomatic vines. PLoS One 2014;9:e95928. https://doi.org/10.1371/journal.pone.0095928.

53. Fischer M, Schneider P, Kraus C, Molnar M, Dubois C, d’Aguiar D, Haag N. Grapevine trunk disease in German viticulture: occurrence of lesser known fungi and first report of Phaeoacremonium viticola and P. fraxinopennsy/vanicum. Vitis. 2016;55(4):145-156. https://doi.org/10.5073/vitis.2016.55.145-156.

54. Gomzhina MM, Gasich EL, Khlopunova LB, Gannibal PB. Paraphoma species associated with Convolvulaceae. Mycol Prog. 2020;19(3):185-194. https://doi.org/10.1007/s11557-020-01558-8.

55. Pinto C, dos Santos Custodio V, Nunes M, Songy A, Rabenoelina F, Courteaux B, Clement C, CatarinaGomes A, Fontaine F. Understand the potential role of Aureobasidium pullulans, a resident microorganism from grapevine, to prevent the infection caused by Diplodia seriata. Front. Microbiol. 2018;9:3047. https://doi.org/10.3389/fmicb.2018.03047.

56. Munkvold GP, Marois JJ. Efficacy of natural epiphytes and colonisers of grapevine pruning wounds for biological control of Eutypa dieback. Phytopathology 1993; 83: 624-629.

57. Halleen F, Mostert L, Crous PW. Pathogenicity testing of lesser-known vascular fungi of grapevines. Australas Plant Pathol. 2007;36:277-285. https://doi.org/10.1071/AP07019.

58. Úrbez-Torres JR, Leavitt GM, Guerrero JC, Guevara J, Gubler, WD. Identification and pathogenicity of Lasiodiplodia theobromae and Diplodia seriata, the causal agents of Bot canker diseases of grapevines in Mexico. Plant Dis. 2008; 92:519-529. https://doi.org/10.1094/PDIS-92-4-0519.

59. Úrbez-Torres JR, Gubler WD. Pathogenicity and epidemiology of Botryosphaeriaceae from grapevines in California. Plant Dis. 2009;93(6):584-592. https://doi.org/10.1094/PDIS-93-6-0584.

60. Spagnolo A, Marchi G, Peduto F, Phillips A, Surico, G. Detection of Botryosphaeriaceae species within grapevine woody tissues by nested PCR, with particular emphasis on the Neofusicoccum parvum/ $\mathrm{N}$. ribis complex. Eur J Plant Pathol. 2011;129:485-500. https://doi.org/10.1007/s10658-010-9715-9.

61. Aroca A, García-Figueres F, Bracamonte L, Luque J, Raposo R. A survey of trunk disease pathogens within rootstocks of grapevines in Spain. Eur J Plant Pathol. 2006;115:195-202. https://doi.org/10.1007/s10658-006-9008-5.

62. Waite H, Gramaje D, Whitelaw-Weckert M, Torley P, Hardie J. Soaking grapevine cuttings in water: a potential source of cross contamination by micro-organisms. Phytopathol. Mediterr. 2013;52:359368.

63. Agustí-Brisach C, Armengol J. Black-foot disease of grapevine: an update on taxonomy, epidemiology and management strategies. Phytopathol Mediterr. 2013;52(2):245-261. https://www.jstor.org/stable/42685404.

64. Halleen F, Crous RW, Petrin O. Fungi associated with healthy grapevine cuttings in nurseries, with special reference to pathogens involved in the decline of young vines. Aust Plant Pathol. 2003;32:47-52. https://doi.org/10.1071/AP02062. 
65. Agustí-Brisach C, Gramaje D, García-Jiménez J, Armengol J. Detection of black-foot disease pathogens in the grapevine nursery propagation process in Spain. Eur J Plant Pathol. 2013;137:103112. https://doi.org/10.1007/s10658-013-0221-8.

66. Armengol J, Gramaje D. Soilborne fungal pathogens affecting grapevine rootstocks: current status and future prospects. Acta Hortic. 2016; 1136:235-238. https://doi.org/ 10.17660/ActaHortic.2016.1136.32.

67. Billones-Baaijens R, Jaspers M, Allard A, Hong Y, Ridgway H, Jones E. Management of Botryosphaeriaceae species infection in grapevine propagation materials. Phytopathol. Mediterr. 2015; 54:355-367.

68. Probst C, Jones EE, Ridgway HJ, Jaspers MV. 2012. Cylindrocarpon black foot in nurseries-two factors that can increase infection. Australas. Plant Pathol. 2012; 41:157-163. http://dx.doi.org/10.1007/s13313-011-0103-5.

69. Whitelaw-Weckert M, Rahman L, Appleby LM, Hall A, Clark AC, Waite H, Hardie WJ. Co-infection by Botryosphaeriaceae and llyonectria spp. fungi during propagation causes decline of young grafted grapevines. Plant. Pathol. 2013; 62:1226-1237. https://doi.org/10.1111/ppa.12059.

70. Amend AS, Seifert KA, Bruns TD. Quantifying microbial communities with 454 pyrosequencing: does read abundance count? Mol Ecol. 2010;19:5555-5565. https://doi.org/10.1111/j.1365294X.2010.04898.x.

71. Holland T, Bowen P, Kokkoris V, Urbez-Torres JR, Hart M. Does inoculation with arbuscular mycorrhizal fungi reduce trunk disease in grapevine rootstocks? Horticulturae. 2019;5(3):61. https://doi.org/10.3390/horticulturae5030061.

72. Martínez-Diz MP, Andrés-Sodupe M, Berbegal M, Bujanda R, Díaz-Losada E, Gramaje D. Droplet digital PCR technology for detection of Ilyonectria liriodendri from grapevine environmental samples. Plant Dis. 2020b;104(4):1144-1150. https://doi.org/10.1094/PDIS-03-19-0529-RE.

73. Takamatsu H, Mura R, Zheng J, Moorhead M, Yasushi T, Takashi Y, Faham M, Nakao S. A Comparison between next-generation sequencing and ASO-qPCR for minimal residual disease detection in multiple myeloma: the clinical value in ASCT setting. Blood. 2013;122(21):1843. https://doi.org/10.1182/blood.V122.21.1843.1843.

74. Gao J, Wu H, Shi X, Huo Z, Zhang J, Liang Z. Comparison of next-generation sequencing, quantitative PCR, and sanger sequencing for mutation profiling of EGFR, KRAS, PIK3CA and BRAF in clinical lung tumors. Clin Lab. 2016;62(4):689-96. https://doi.org/10.7754/clin.lab.2015.150837.

75. Halleen F, Fourie PH. An integrated strategy for the proactive management of grapevine trunk disease pathogen infections in grapevine nurseries. S. Afr. J. Enol. Vitic. 2016; 37:104-114.

76. Gramaje D, Alaniz S, Abad-Campos P, García-Jimenez J, Armengol J. Effect of hot-water treatments in vitro on conidial germination and mycelial growth of grapevine trunk pathogens. Ann. Appl. Biol. 2010b; 231-241.

77. Berbegal M, Ramón-Albalat A, León M, Armengol J. 2020. Evaluation of long-term protection from nursery to vineyard provided by Trichoderma atroviride SC1 against fungal grapevine trunk 
pathogens. Pest Manag. Sci. 2020; 76:967-977. https://doi.org/10.1002/ps.5605.

78. Ramsing CK, Gramaje D, Mocholi S, Agustí J, Cabello Saénz de Santa María F, Armengol J, Berbegal M. Relationship between the xylem anatomy of grapevine rootstocks and their susceptibility to Phaeoacremonium minimum and Phaeomoniella chlamydospora. Frontiers Plant. Sci. 12:726461.

79. Berlanas C, Andrés-Sodupe M, López-Manzanares B, Maldonado-González MM, Gramaje D. Effect of white mustard cover crop residue, soil chemical fumigation and Trichoderma spp. root treatment on black-foot disease control in grapevine. Pest Manag Sci. 2018;74:2864-2873. https://doi.org/10.1002/ps.5078.

\section{Supplementary Files}

This is a list of supplementary files associated with this preprint. Click to download.

- FigS1.tiff

- FigS2.tiff

- FigS3.tiff

- FigS4.tiff

- FigS5.tiff

- Figs6.tiff

- FigureSuppcaptions.docx

- SupplementaryTables.docx 